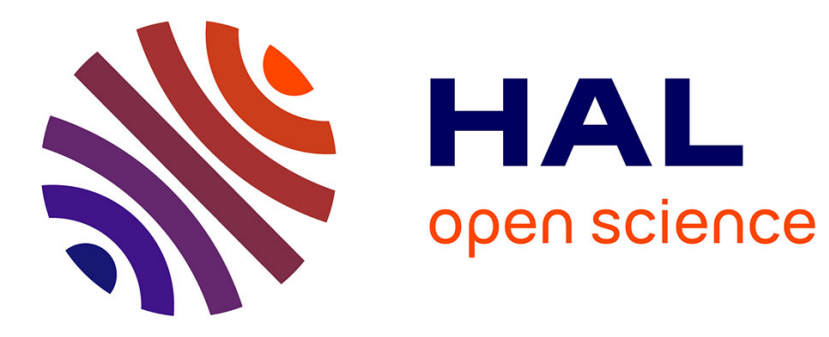

\title{
Does this patient have Ebola virus disease?
}

Pierre Tattevin, Emanuele Durante-Mangoni, Moses Massaquoi

\section{To cite this version:}

Pierre Tattevin, Emanuele Durante-Mangoni, Moses Massaquoi. Does this patient have Ebola virus disease?. Intensive Care Medicine, 2014, 40 (11), pp.1738-41. 10.1007/s00134-014-3473-7 . hal01096514

\section{HAL Id: hal-01096514 \\ https://hal-univ-rennes1.archives-ouvertes.fr/hal-01096514}

Submitted on 17 Dec 2014

HAL is a multi-disciplinary open access archive for the deposit and dissemination of scientific research documents, whether they are published or not. The documents may come from teaching and research institutions in France or abroad, or from public or private research centers.
L'archive ouverte pluridisciplinaire HAL, est destinée au dépôt et à la diffusion de documents scientifiques de niveau recherche, publiés ou non, émanant des établissements d'enseignement et de recherche français ou étrangers, des laboratoires publics ou privés. 


\section{WHAT'S NEW IN INTENSIVE CARE}

\section{Does this patient have Ebola virus disease?}

Short Running Title: Ebola Virus Disease

\section{Pierre Tattevin}

\section{Emanuele Durante-Mangoni}

\section{Moses Massaquoi}

P. Tattevin

Infectious Diseases and Intensive Care Unit, Pontchaillou University Hospital, INSERM U835, Université Rennes-I, Rennes, France

E. Durante-Mangoni

Internal Medicine, University of Naples SUN, Ospedale Monaldi, Naples, Italy

\section{Massaquoi}

National Case Management Chair, Ebola Response \& Ministry of Health and Social Welfare, Monrovia, Liberia. Country Director, Clinton Health Access Initiative, Monrovia, Liberia

Corresponding author: P. Tattevin, Service des Maladies Infectieuses et Réanimation Médicale, CHU Pontchaillou, 2 rue Henri Le Guilloux, 35033 Rennes Cedex, France. Phone : (33) 299289549. Fax: (33) 299289464. E-mail: pierre.tattevin@chu-rennes.fr

\section{Declaration of interest}

The authors declare that they have no conflict of interest. 


\section{Introduction}

Ebola virus is one of the most virulent human pathogens. Since 1976, Ebola virus disease (EVD) has caused more than 20 outbreaks in Africa, with case fatality rates of $30 \%-90 \%$, in the absence of any approved treatment or vaccination [1]. It is transmitted by direct contact through broken skin or mucous membranes with blood, urine, saliva, feces, vomit, and other body fluids of symptomatic infected patients or convalescent persons, or through contaminated needle sticks $[1,2]$. The current outbreak in West Africa probably begun in December 2013 in Guinea [3], and causes unprecedented concerns for the following reasons:

i) It is due to a strain with $97 \%$ homology with Zaire ebolavirus, the most virulent species, with prior fatality rates as high as $90 \%$; ii) As of August $22^{\text {nd }}$, four countries have been involved, with 2,615 suspected cases, 1,528 laboratory confirmed cases, and 1,427 related deaths: this is already much more than the largest epidemic reported to date (425 cases in Uganda, 2000-2001), and the situation is unlikely to be resolved soon [4, 5]; iii) The 2014 West Africa outbreak affects rural as well as urban areas, and recently reached the most populous African country (Nigeria); iv) Experienced governmental and non-governmental organizations, including Médecins Sans Frontières (MSF), have been active on the field since March 2014 [3], but failed to control the epidemic.

Many factors contributed to this failure, including population poverty and authorities' distrust, disease denial in the context of strong religious beliefs, porous borders, weaknesses in public health systems, inadequate salaries and lack of adequate protection for health care workers. On August 8, nine months after the first documented cases, the World Health Organization (WHO) has declared this outbreak a public health emergency of international concern and has called for a strong and coordinated international response, stating that 'all nations should be prepared to detect, investigate, and manage Ebola cases' [6]. 


\section{Ebola virus disease outside Africa}

The risk that this outbreak will establish a foothold in high-income countries outside Africa is very low, as human-to-human transmission of EVD does not occur when adequate infection control procedures are implemented. However, patients with EVD acquired in West Africa have already been transferred to America and Europe, and this is likely to become more common as the disease spreads. Hence, physicians working in emergency departments or intensive care units (ICU) outside Africa must be able to identify patients with possible EVD, and manage them appropriately, with two main objectives: i) prevent any human-tohuman transmission of Ebola virus in contacts, including health care workers, relatives, and other patients; ii) ensure all EVD suspected patients receive appropriate care, whether or not affected. We aimed to describe epidemiological, clinical and biological clues that may be used to classify patients with suspected EVD.

\section{Epidemiological clues}

As of August 2014, EVD has been essentially transmitted in three countries during the current outbreak: Guinea, Liberia, and Sierra Leone (Fig. 1). A fourth country, Nigeria, was more recently added to the list of countries where transmission of Ebola virus occurs, which documents that spread may occur in countries not bordering the original epidemic area. For case definition, the Centers for Disease Control and Prevention (CDC) consider that residence in, or travel to an area where EVD transmission is active, is a risk factor for EVD (http://www.cdc.gov/vhf/ebola/hcp/case-definition.html). Although this makes sense for operational reasons, two issues deserve consideration. Firstly, outbreaks are dynamic processes, and this is particularly true for this EVD epidemic. Hence, we have no guarantee that countries bordering with areas of active transmission (e.g. Mali, Ivory Coast), or even more remote African countries, will remain EVD-free. This remark is not an invitation to 
prematurely increase the list of countries to be considered at risk for EVD exposure, but a word of caution to governments and clinicians: in the context of the current outbreak, a patient returning from countries neighbouring those mentioned above, and presenting with fever, a severe illness, haemorrhagic symptoms, and no alternative diagnosis, should raise attention. Secondly, in subjects coming back from one of the four EVD countries, the level of exposure may differ from almost zero (e.g. airlines staff or passengers in transit who spent a few hours in a local airport), to very high (e.g. health care staff working in an Ebola treatment unit).

The second epidemiological clue is the incubation time or window period, conservatively defined as [3-21 days]. These limits allow to rule out EVD in any patient with fever onset later than 21 days after returning from an endemic area. More reliable data, obtained in settings where a single well-defined exposure had occurred, indicated a range of 3-13 days for the incubation period (mean, 6-8 days). However, the mean incubation period may vary according to the inoculum and the route of infection, averaging at 9.5 days for contact exposures, and 6.3 days after injection during the 1976 Zaire ebolavirus outbreak [7, 8].

\section{Clinical findings suggestive of Ebola virus disease}

High-grade fever is a necessary criteria for EVD in most case definitions. Indeed, in all published series, fever was present in $>97 \%$ of cases [1, 2, 9-19], and a literature review found that 791 of 796 cases of EVD presented with a body temperature $\geq 101^{\circ} \mathrm{F}$, or $38.3^{\circ} \mathrm{C}$ [9]. Typically, fever is of abrupt onset, associated with flu-like symptoms (chills, malaise, arthromyalgias), and soon followed by digestive manifestations $[1,2]$. In the current West Africa outbreak, severe diarrhea and vomiting have been invariably observed during the early disease course [3]. Subsequent signs and symptoms are variable, mostly respiratory (chest 
pain, shortness of breath, cough), cutaneous (in $25-50 \%$ of cases, a mostly non-itchy, diffuse maculopapular rash with secondary desquamation occurs), and neurological (confusion). Brain involvement translates into a significant occupational risk for health care workers, as patients may become aggressive. Haemorrhagic manifestations, once considered the hallmark of EVD, arise during the peak of the illness in 50 to $70 \%$ of patients, and may vary from petechiae to multiple foci of mucosal haemorrhage, up to uncontrolled bleeding after injections or vessel punctures. In fatal cases, death usually occurs between day 6 and day 16, due to a combination of hypovolaemic and septic shock, massive bleeding (typically gastrointestinal), and multiorgan failure.

\section{Laboratory abnormalities}

Due to limited access to laboratory tests in involved countries, and the risk associated with improper handling of blood samples, less is known on laboratory features of EVD [1, 13]. Most patients show early moderate leukopenia, with deep lymphopenia attributed to massive apoptosis. Later, neutrophilia, and/or atypical lymphocytes appear. Other common findings include moderate thrombocytopenia (50,000-100,000 cells per $\mu \mathrm{L})$, highly raised liver enzymes (especially aspartate aminotransferase), hyperproteinemia (possibly related to capillary leak), and prolongation of prothrombin and thromboplastin times, often in the context of disseminated intravascular coagulation. No specific abnormalities have been reported at later stages, when multiorgan failure ensues.

\section{Differential diagnosis}

The definite EVD diagnosis hinges on detection of viral antigen by enzyme-linked immunosorbent assay or viral RNA by polymerase-chain-reaction. IgM and IgG antibodies may become positive later in the course of illness. Alternative diagnoses must be carefully 
considered and ruled out, especially when early treatment may favourably impact prognosis (e.g. malaria, any bacterial severe sepsis or septic shock, enteric fever, leptospirosis, rickettsiosis, African trypanosomiasis). This is one of the main challenges in the management of suspected EVD, as the recommended infection control measures for collecting and handling biological specimens may delay necessary laboratory testing (e.g. traditional chemistry, hematology, blood cultures, malaria tests, serology), and jeopardize patient care, if not promptly performed. Likewise, basic imaging studies (ultrasound, chest X-ray) should not be deferred, provided adequate protection is used, so that the necessary process to rule out EVD in suspected cases will not translate into a loss of opportunity for those with alternative diagnosis. Of note, common detergents and hypochlorite are effective in neutralising Ebola virus.

\section{Conclusions}

The 2014 EVD outbreak in West Africa is a public health emergency of international concern [6]. Given the extent of this outbreak, and the flow of transcontinental exchanges, every physician active in emergency departments or ICU worlwide may turn out to be involved in the care of patients suspected of EVD. Take-home messages from this paper, as of August 2014, are i) suspect EVD in any patient who presents with fever within three weeks after a stay in Guinea, Sierra Leone, Liberia, or Nigeria; ii) while implementing infection control procedures to prevent any secondary cases (in case EVD is confirmed), ensure that all plausible differential diagnoses are appropriately considered and managed. 
Fig. 1. Distribution of EVD cases (confirmed, probable and suspected) by district in the affected countries from December 2013 to 16 August 2014

Source: European Centres for Disease Control and Prevention, adapted from National Reports and WHO

(http://ecdc.europa.eu/en/press/news/_layouts/forms/News_DispForm.aspx?List=8db7286cfe2d-476c-9133-18ff4cb1b568\&ID=1047)

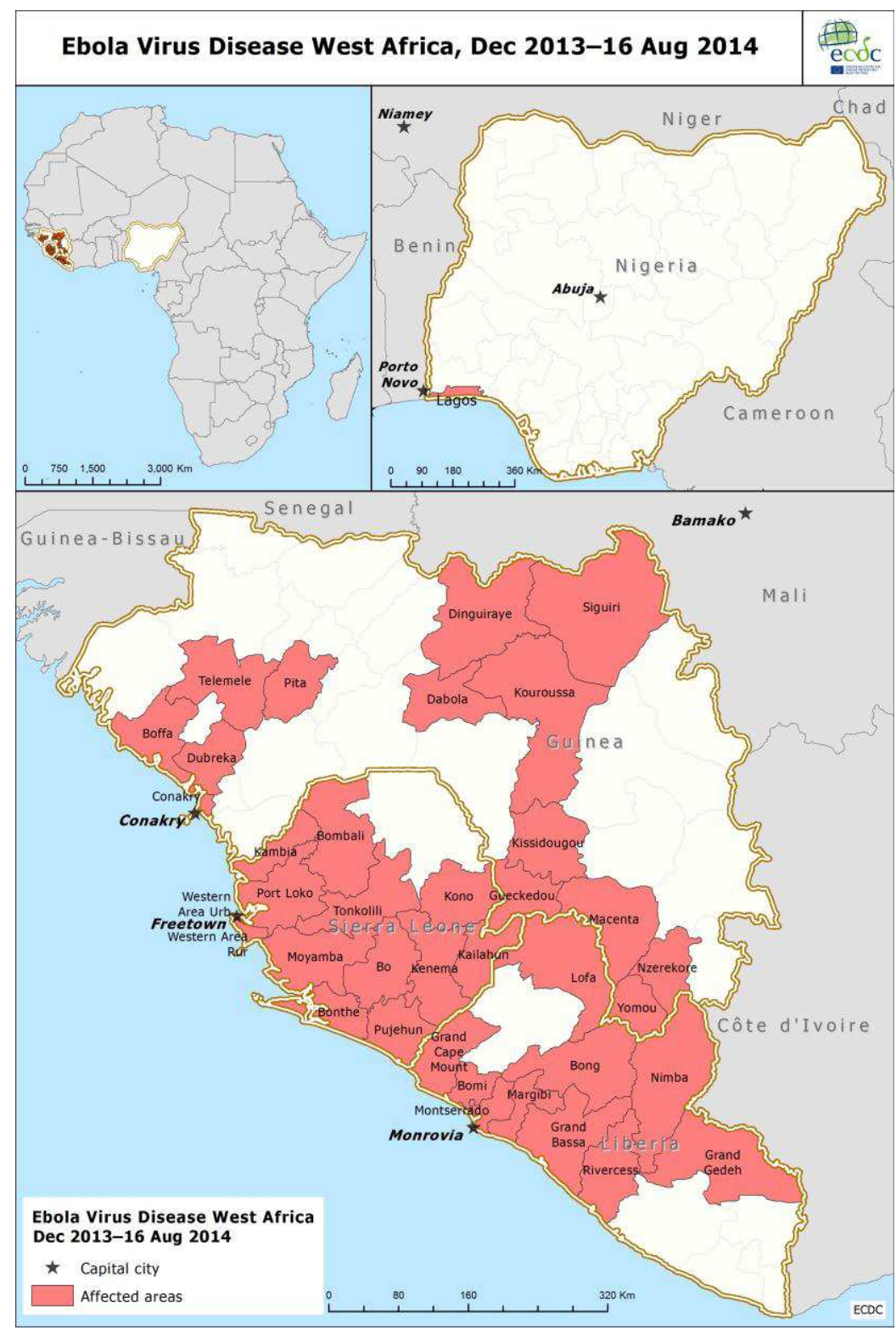




\section{References}

1. Feldmann H, Geisbert TW: Ebola haemorrhagic fever. Lancet 2011, 377(9768):849-862.

2. Colebunders R, Borchert M: Ebola haemorrhagic fever--a review. J Infect 2000, 40(1):1620.

3. Baize S, Pannetier D, Oestereich L, Rieger T, Koivogui L, Magassouba N, Soropogui B, Sow MS, Keita S, De Clerck H et al: Emergence of Zaire Ebola Virus Disease in Guinea Preliminary Report. N Engl J Med 2014.

4. Fauci AS: Ebola - Underscoring the Global Disparities in Health Care Resources. N Engl J Med 2014.

5. Chan M: Ebola Virus Disease in West Africa - No Early End to the Outbreak. $N$ Engl $J$ Med 2014.

6. Hawkes $\mathrm{N}$ : Ebola outbreak is a public health emergency of international concern, WHO warns. BMJ 2014, 349:g5089.

7. Ebola haemorrhagic fever in Zaire, 1976. Bull World Health Organ 1978, 56(2):271-293.

8. Ebola haemorrhagic fever in Sudan, 1976. Report of a WHO/International Study Team. Bull World Health Organ 1978, 56(2):247-270.

9. Pittalis S, Fusco FM, Lanini S, Nisii C, Puro V, Lauria FN, Ippolito G: Case definition for Ebola and Marburg haemorrhagic fevers: a complex challenge for epidemiologists and clinicians. New Microbiol 2009, 32(4):359-367.

10. Hartman AL, Towner JS, Nichol ST: Ebola and marburg hemorrhagic fever. Clin Lab Med 2010, 30(1):161-177.

11. MacNeil A, Farnon EC, Wamala J, Okware S, Cannon DL, Reed Z, Towner JS, Tappero JW, Lutwama J, Downing R et al: Proportion of deaths and clinical features in Bundibugyo Ebola virus infection, Uganda. Emerg Infect Dis 2010, 16(12):1969-1972.

12. Borchert M, Mutyaba I, Van Kerkhove MD, Lutwama J, Luwaga H, Bisoborwa G, Turyagaruka J, Pirard P, Ndayimirije N, Roddy P et al: Ebola haemorrhagic fever outbreak in Masindi District, Uganda: outbreak description and lessons learned. BMC Infect Dis 2011, 11:357.

13. Kortepeter MG, Bausch DG, Bray M: Basic clinical and laboratory features of filoviral hemorrhagic fever. J Infect Dis 2011, 204 Suppl 3:S810-816.

14. Sureau PH: Firsthand clinical observations of hemorrhagic manifestations in Ebola hemorrhagic fever in Zaire. Rev Infect Dis 1989, 11 Suppl 4:S790-793.

15. Bwaka MA, Bonnet MJ, Calain P, Colebunders R, De Roo A, Guimard Y, Katwiki KR, Kibadi K, Kipasa MA, Kuvula KJ et al: Ebola hemorrhagic fever in Kikwit, Democratic Republic of the Congo: clinical observations in 103 patients. J Infect Dis 1999, 179 Suppl 1:S1-7.

16. Khan AS, Tshioko FK, Heymann DL, Le Guenno B, Nabeth P, Kerstiens B, Fleerackers Y, Kilmarx PH, Rodier GR, Nkuku $O$ et al: The reemergence of Ebola hemorrhagic fever, Democratic Republic of the Congo, 1995. Commission de Lutte contre les Epidemies a Kikwit. J Infect Dis 1999, 179 Suppl 1:S76-86.

17. Ndambi R, Akamituna P, Bonnet MJ, Tukadila AM, Muyembe-Tamfum JJ, Colebunders R: Epidemiologic and clinical aspects of the Ebola virus epidemic in Mosango, Democratic Republic of the Congo, 1995. J Infect Dis 1999, 179 Suppl 1:S8-10.

18. Richards GA, Murphy S, Jobson R, Mer M, Zinman C, Taylor R, Swanepoel R, Duse A, Sharp $G$, De La Rey IC et al: Unexpected Ebola virus in a tertiary setting: clinical and epidemiologic aspects. Crit Care Med 2000, 28(1):240-244.

19. Outbreak of Ebola hemorrhagic fever Uganda, August 2000-January 2001. MMWR Morb Mortal Wkly Rep 2001, 50(5):73-77. 